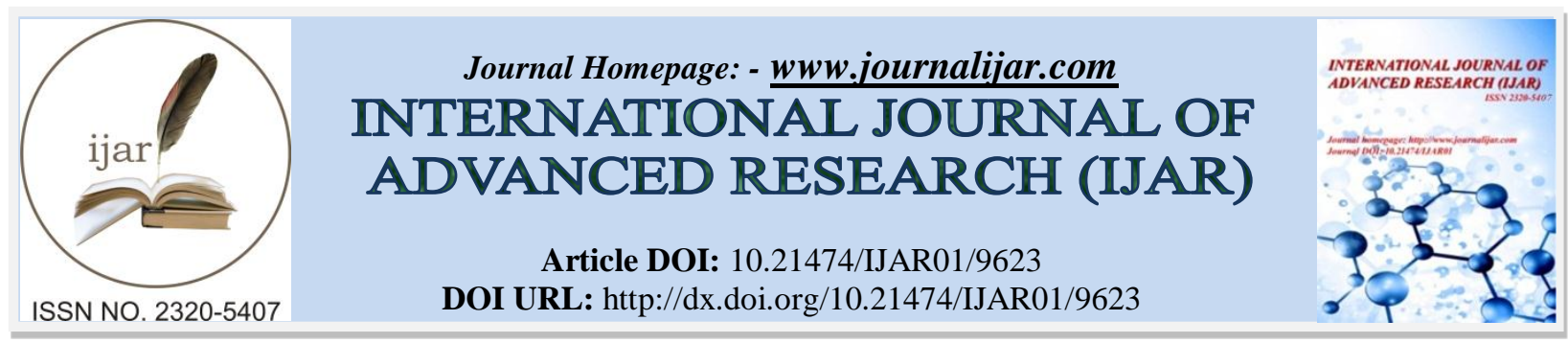

RESEARCH ARTICLE

\title{
EVALUATION OF THE SEALING ABILITY OF BIODENTINE AS A RETROGRADE FILLING MATERIAL.
}

Dr. Ghoson Ahmad Ibrahim ${ }^{1}$, Dr. Majed Hasan Amran ${ }^{2}$ and Prof. Aziz Zuhair Abdullah ${ }^{3}$.

1. DDS, Msc, Tishreen University, Syria.

2. DDS, MSc, Tishreen University, Syria.

3. Head of endodontics and operative dentistry in Tishreen University in Syria, Visiting professor at Hamburg University in Germany.

\section{Manuscript Info}

n.......................

Manuscript History

Received: 02 July 2019

Final Accepted: 04 August 2019

Published: September 2019

Key words:-

MTA, Biodentine, retrograde, microleakage.

\section{Abstract}

Aim: The aim of this study was to compare the sealing ability of biodentine with mineral trioxide aggregate (MTA) by dye leakage test using methylene blue.

Materials and methods: thirty human single-rooted teeth were prepared and the canals were instrumented using standard method up to \# 40, and obturated with gutta-percha and zinc oxide. The ends of the roots were resected at $3 \mathrm{~mm}$ away from the apices, and the retrograde cavities were prepared using fissure bur. The teeth were divided into two groups ( $\mathrm{n}=15$ for each group); first group was filled with MTA, and the second with Biodentine. The teeth immersed in the methylene blue $2 \%$ for 24 hours. Then the teeth were cut longitudinally and the dye leakage was measured in millimeter under the stereoscope.

Results: There was no statistically significant difference between the two groups from the way of sealing ability $(\mathrm{P}>0.05)$.

Conclusion: Under the conditions of this study: it could be concluded that Biodentine has the same apical sealing ability compared with MTA when it used as a retrograde filling material.

Copy Right, IJAR, 2019,. All rights reserved.

\section{Introduction:-}

The success of endodontic treatment depends on the debridement of the root canal then the ability to obturate it with a sealing material. Many material, instruments and techniques have been developed to reach this success. (Özata et al., 1993; Sousa et al., 2004). However, the periapical lesion may persist in some cases. In these cases, the apicoectomy become indication (Holt and Dumsha, 2000; Sousa et al., 2004).

Surgical procedure includes exposure of the apex, resection the end of the root, preparation the cavity and insert the root end filling material, which should adhere to the cavity walls to provide a tight seal against the microorganisms and their byproducts. Also, it should be radiopaque, dimensionally stable, nonabsorbable, and the most important easy to handle (Ingle, 2009; Ingle and Bakland, 2002)

Numerous materials have been recommended to be used as retrograde material such as: amalgam, zinc oxideeugenol cements, polycarboxylate, glass ionomer cement and Mineral Trioxide Aggregate (MTA). MTA has been used for apexification, perforation repair, root resorption, and as root-end filling material (Torabinejad and Chivian, 
1999). it consists of many components such as: tricalcium silicate, tricalcium aluminate, tricalcium oxide, and silicate oxide. Mineral Trioxide Aggregate (MTA) has shown good sealing ability and biocompatibility in previous in-vitro and in-vivo studies. (Parirokh and Torabinejad, 2010).

Biodentine is a new material based on calcium silicate technology.it consists of powder and liquid. The powder consists of: dicalcium silicate, tricalcium silicate, calcium carbonate and iron oxide, and zirconium oxide filler. the Liquid consists of calcium chloride which is acting as accelerator and a polymer which is acting as a water reducing agent. Biodentine has good handling properties. it can be used as a retrograde filling material (Grech et al., 2013)

The quality of apical seal achieved by root end filling materials can be assessed by various methods like the degree of dye penetration, and fluid filtration techniques ( Wu and Wesselink, 1993). The dye penetration is the most popular method for measuring sealing ability of the root canal. Various dyes that can be used include India ink, basic fuchsin, and methylene blue. methylene blue has been proved to be a useful aid in endodontics (Ahlberg et al., 1995).

The aim of this study was to evaluate the sealing ability of Biodentine as retrograde filling materials.

\section{Materials and Methods:-}

thirty extracted single rooted human teeth with completely formed apices and straight canals were taken for this study. The teeth were cleaned, disinfected and stored in normal saline. The crowns of the teeth were cut at the cementoenamel junction and the length of each sample was standardized to $14 \mathrm{~mm}$ using a diamond disk. The length of each canal was visually determined by placing a \#15 file into the canal until the tip of the file was visible at the apex. The working length was determined by subtracting $1 \mathrm{~mm}$ from the length of the file. The canals were prepared up to \#40 using the standard method. Sodium hypochlorite 5.25\% was used after each filing motion. The final irrigation was done with EDTA $17 \%$.

Canals were dried using absorbent paper points and obturated with gutta-percha points and zinc oxide eugenol sealer with lateral compaction technique. Radiographs were taken to confirm the quality of obturation. Canal orifices were sealed with class ionomer cement and the teeth were stored in incubation at $37^{\circ} \mathrm{C}$ and 100 humidity for one week.

The root resections were carried out using a fissure bur (FG $111 \mathrm{x} 014$ horico, Germany) at $90^{\circ}$ angle axis to the long axis of the root removing $3 \mathrm{~mm}$ of the apex. 3mm deep root end cavity was prepared using FG108x010 fissure bur (figure 1,2). Depth of the root end cavity was checked using periodontal probe. All the root end cavities were rinsed with EDTA as final irrigation.

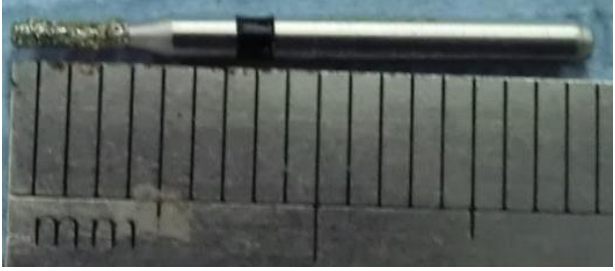

Figure 1:-FG108x010 fissure bur

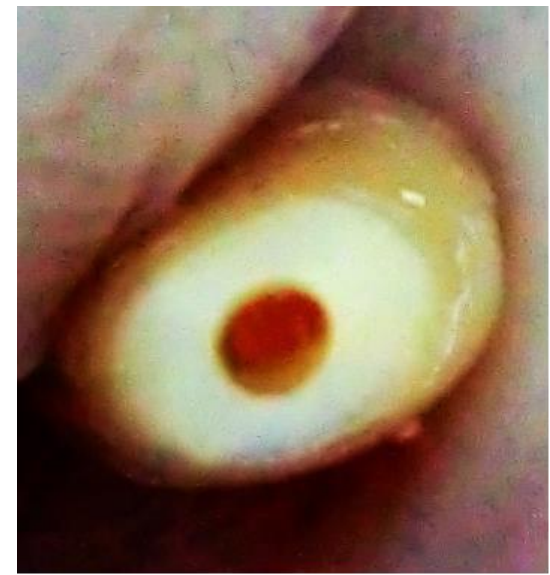

Figure 2:-the prepared root end cavity. 
The teeth were randomly divided into two groups of 15 each: group 1: root end cavities were restored with MTA (chungcheongbuk-do, Korea) while the root end cavities were filled with Biodentine (saint-Maurd-des-fosses Codex-France) in group 2. The used root end filling materials were manipulated according to the manufacture's instructions. Each material was condensed into the prepared cavity using small pluggers. the root end filling material were allowed to set for one day at $37^{\circ} \mathrm{C}$ and $100 \%$ humidity. After that the samples were coated with 3 layers of nail varnish except for $1 \mathrm{~mm}$ from the apex and then allowed to dry completely.

The specimens were then suspended in $2 \%$ methylene blue for 24 hours. After that the teeth were rinsed under running water. The teeth were split longitudinally with a diamond disc using a water coolant and the dye penetration was examined under stereomicroscope \& microleakage was evaluated in millimeters under stereoscope. When the sample showed no leakage, a part of the root end filling material was removed to make sure that there was not a hidden leakage under it (figure 3,4 and 5).

\section{Statistical analysis:-}

The results of the leakage test were statistically evaluated using Independent Samples Test. The results were expressed as means \pm standard deviation, and $P<0.05$ was considered statistically significant as in table (1) and table (2).

Table 1:-shows the mean microleakage of the samples.

\begin{tabular}{|l|c|c|c|c|c|}
\hline \multicolumn{7}{|c|}{ Group Statistics } \\
\hline & MATERIAL & $\mathrm{N}$ & Mean & Std. Deviation & Std. Error Mean \\
\hline \multirow{2}{*}{ MICROLEAKAGE } & BIODENTIN & 15 & 1.3000 & .70204 & .18127 \\
\cline { 2 - 6 } & MTA & 15 & 1.0333 & .54989 & .14198 \\
\hline
\end{tabular}

Table 2:-shows the results of Independent Samples Test.

\begin{tabular}{|c|c|c|c|c|c|c|c|c|c|c|}
\hline \multicolumn{11}{|c|}{ Independent Samples Test } \\
\hline & & \multicolumn{2}{|c|}{$\begin{array}{l}\text { Levens's } \\
\text { test for } \\
\text { Equality of } \\
\text { variances }\end{array}$} & \multicolumn{7}{|c|}{ T_test for Equality of Means } \\
\hline & & \multirow[t]{2}{*}{$\mathrm{f}$} & \multirow[t]{2}{*}{ sig } & \multirow[t]{2}{*}{$\mathrm{t}$} & \multirow[t]{2}{*}{ df } & \multirow{2}{*}{$\begin{array}{c}\text { Sig. } \\
(2- \\
\text { tailed })\end{array}$} & \multirow{2}{*}{$\begin{array}{c}\text { Mean } \\
\text { difference }\end{array}$} & \multirow{2}{*}{$\begin{array}{l}\text { Std error } \\
\text { difference }\end{array}$} & \multicolumn{2}{|c|}{$95 \%$ confidence } \\
\hline & & & & & & & & & lower & upper \\
\hline \multirow[t]{2}{*}{ Microleakage } & $\begin{array}{c}\text { Equal } \\
\text { variances } \\
\text { assumed }\end{array}$ & 1.793 & .191 & 1.158 & 28 & .257 & .26667 & .23025 & $\begin{array}{c}- \\
.20498\end{array}$ & .73832 \\
\hline & $\begin{array}{c}\text { Equal } \\
\text { variances } \\
\text { not } \\
\text { assumed }\end{array}$ & & & 1.158 & 26.48 & 257 & .26667 & .23025 & $\begin{array}{c}- \\
.20620\end{array}$ & $\begin{array}{c}- \\
.73954\end{array}$ \\
\hline
\end{tabular}

\section{Results:-}

The overall results showed that the mean microleakage was maximum for Biodentine. However, the difference between MTA and Biodentine was not statistically significant $(\mathrm{P}<0.05)$. 
Graph 1:-shows the sealing ability of Biodentine was similar to that of MTA.

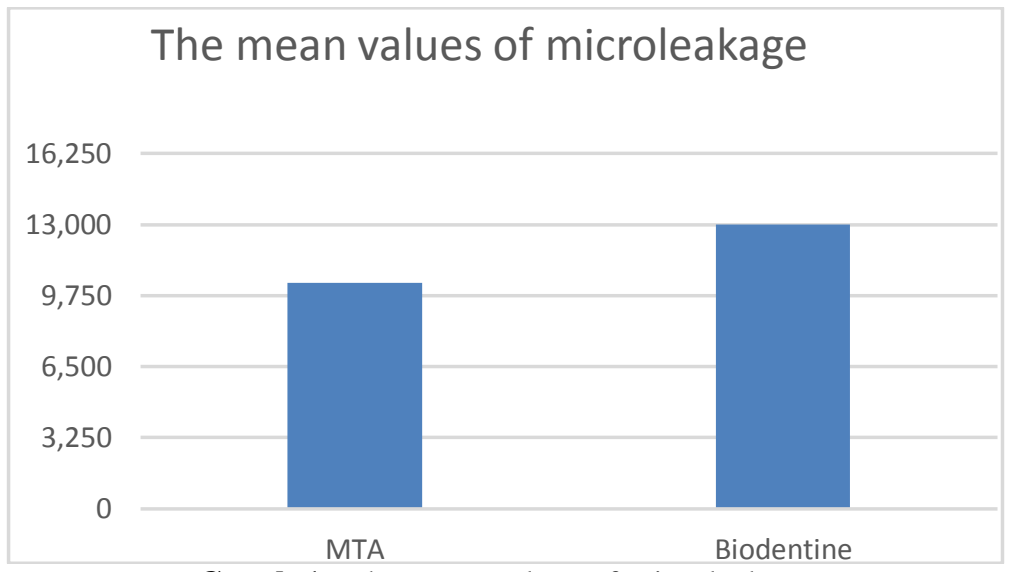

Graph 1:-The mean values of microleakage

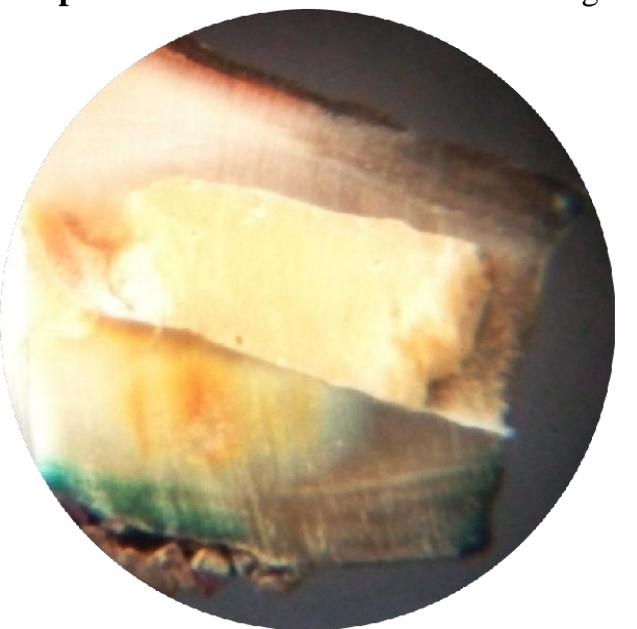

Figure 3:-One of MTA sample shows no leakage.

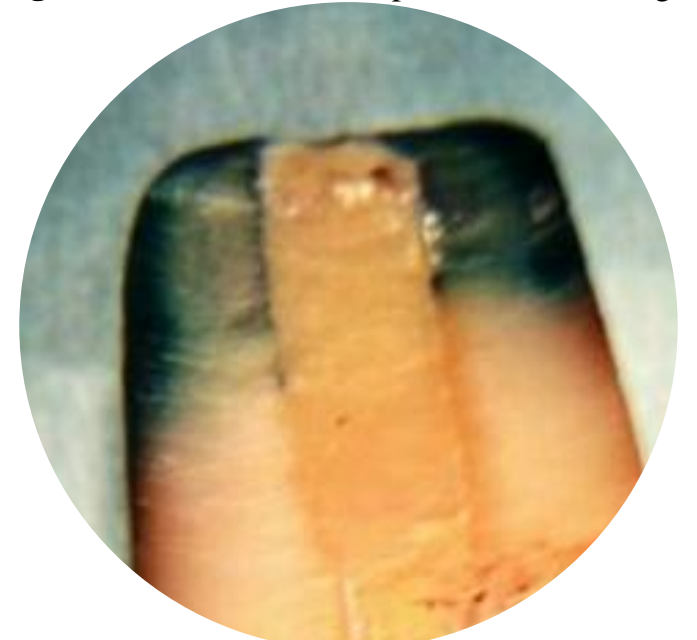

Figure 4:-One of MTA samples shows leakage. 


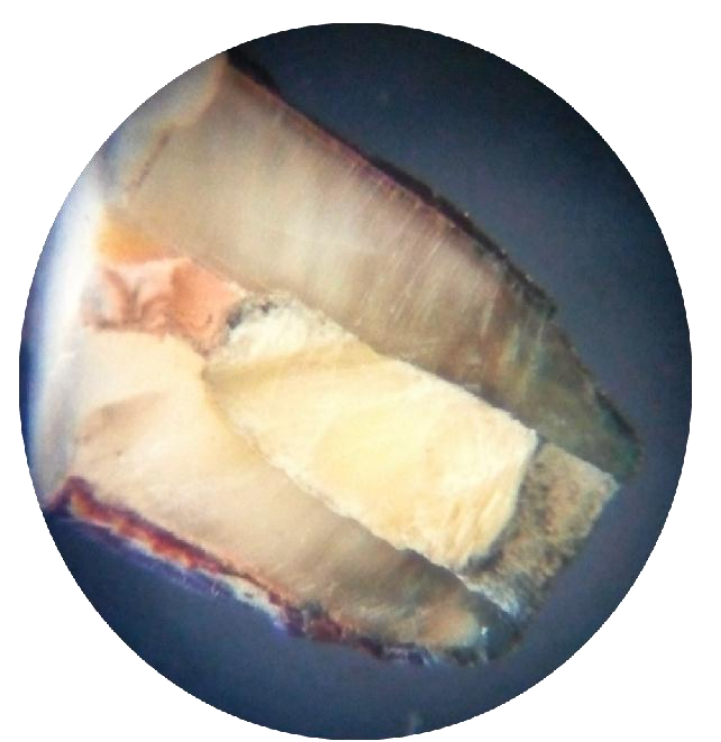

\section{Discussion:}

Figure 5:-One of Biodentine samples shows some leakage.

Most of endodontic retreatment are managed using conventional treatment method. However, some cases require surgical intervention (Hargreaves and Berman, 2015; Ingle and Bakland, 2002). Sealing ability of the retrograde filling material is as important as its biocompatibility for the success of surgical treatment. Poor sealing can be a result of inadequate contact between the filling material and root canal walls (Tsesis et al., 2006).

Mineral trioxide aggregate is frequently used as root end filling material. MTA showed better sealing properties than other material (Khandelwal et al., 2015; Maior et al., 2007; Pereira et al., 2004; Post et al., 2010). Although MTA is showing good results as retrograde filling material, but it has certain limitations such as long setting time and high cost (Sonarkar and Purba, 2015; Swetha et al., 2015). Biodentine uses novel active biosilicate technology to ensure superior mechanical properties. It has got short setting time of around $12 \mathrm{~min}$, which is achieved by the bigger particle size, addition of Calcium chloride to the liquid component and decreasing the overall liquid content. The manufacturers claim that it's modified powder composition i.e., the addition of setting accelerators and softeners, a new pre dosed capsule formulation for use in a mixing device largely improve the physical properties of the material making it more user-friendly (Khandelwal et al., 2015).

the determination of microleakage in dentistry could be performed by various methods and devices such as fluid filtration, dye extraction, dye penetration, bacterial and protein leakage models (Gogna et al., 2011).

This study found that there is no statistically significant difference between Biodentine and MTA regarding the sealing ability as a retrograde filling material. This result is in accordance to the study conducted by Mousavi et al which found that the microleakage values of Biodentine and MTA were similar (Mousavi et al., 2018). On the contrary, Nabeel et al found that the sealing ability of MTA was superior to that of biodentine as root end filling materials (Nabeel et al., 2019). This could be attributed to the fact that they used the Fluid filtration method while dye leakage was used in this study.

Kollmuss et al used the glucose penetration model and also found that MTA was superior to biodentine (Kollmuss et al., 2017). However, Desai et al found that biodentine showed lower leakage values compared to MTA (Desai et al., 2016).

According to this study, the sealing ability of biodentine and MTA was similar as retrograde filling materials.

\section{Conclusion:-}

Within the limits of this study, it can be concluded: that Biodentine has the same sealing ability of MTA as a retrograde filling material. 


\section{References:-}

1. Ahlberg, K.M.F., Assavanop, P., and Tay, W.M. (1995). A comparison of the apical dye penetration patterns shown by methylene blue and India ink in root-filled teeth. Int. Endod. J. 28, 30-34.

2. Desai, N., Rajeev, S., Sahana, S., Jayalakshmi, K.B., Hemalatha, B., Sivaji, K., Vijay, K.R., Vamshi, K.V., Savitri, D., and Gyanendra, P.S. (2016). In vitro comparative evaluation of apical microleakage with three different root-end filling materials. Int J Appl Dent Sci 2, 29-32.

3. Gogna, R., Jagadis, S., and Shashikal, K. (2011). A comparative in vitro study of microleakage by a radioactive isotope and compressive strength of three nanofilled composite resin restorations. J. Conserv. Dent. JCD 14, 128.

4. Grech, L., Mallia, B., and Camilleri, J. (2013). Investigation of the physical properties of tricalcium silicate cement-based root-end filling materials. Dent. Mater. 29, e20-e28.

5. Hargreaves, K.M., and Berman, L.H. (2015). Cohen's pathways of the pulp expert consult (Elsevier Health Sciences).

6. Holt, G.M., and Dumsha, T.C. (2000). Leakage of amalgam, composite, and Super-EBA, compared with a new retrofill material: bone cement. J. Endod. 26, 29-31.

7. Ingle, J.I. (2009). PDQ endodontics (PMPH USA).

8. Ingle, J.I., and Bakland, L.K. (2002). Endodontics (5th edn). BC Decker Hamilt.

9. Khandelwal, A., Karthik, J., Nadig, R.R., and Jain, A. (2015). Sealing ability of mineral trioxide aggregate and Biodentine as root end filling material, using two different retro preparation techniques-An in vitro study. Int $\mathrm{J}$ Contemp Dent Med Rev 2015, 150115.

10. Kollmuss, M., Preis, C.E., Kist, S., Hickel, R., and Huth, K.C. (2017). Differences in physical characteristics and sealing ability of three tricalcium silicate-based cements used as root-end-filling materials. Am. J. Dent. 30, $185-189$.

11. Maior, J.R.S., Figueira, M.A.S., Netto, A., Souza, F.B., Silva, C.H.V., and Tredwin, C.J. (2007). The importance of dentin collagen fibrils on the marginal sealing of adhesive restorations. Oper. Dent. 32, 261-265.

12. Mousavi, S.A., Khademi, A., Soltani, P., Shahnaseri, S., and Poorghorban, M. (2018). Comparison of sealing ability of ProRoot mineral trioxide aggregate, biodentine, and ortho mineral trioxide aggregate for canal obturation by the fluid infiltration technique. Dent. Res. J. 15, 307-312.

13. Nabeel, M., Tawfik, H.M., Abu-Seida, A.M.A., and Elgendy, A.A. (2019). Sealing ability of Biodentine versus ProRoot mineral trioxide aggregate as root-end filling materials. Saudi Dent. J. 31, 16-22.

14. Özata, F., Erdilek, N., and Tezel, H. (1993). A comparative scalability study of different retrofitting materials. Int. Endod. J. 26, 241-245.

15. Parirokh, M., and Torabinejad, M. (2010). Mineral trioxide aggregate: a comprehensive literature review-part I: chemical, physical, and antibacterial properties. J. Endod. 36, 16-27.

16. Pereira, C.L., Cenci, M.S., and Demarco, F.F. (2004). Sealing ability of MTA, Super EBA, Vitremer and amalgam as root-end filling materials. Braz. Oral Res. 18, 317-321.

17. Post, L.K., Lima, F.G., Xavier, C.B., Demarco, F.F., and Gerhardt-Oliveira, M. (2010). Sealing ability of MTA and amalgam in different root-end preparations and resection bevel angles: an in vitro evaluation using marginal dye leakage. Braz. Dent. J. 21, 416-419.

18. Sonarkar, S., and Purba, R. (2015). Bioactive materials in conservative dentistry. Int J Contemp Dent Med Rev $2015,1-4$.

19. Sousa, C.J.A., Loyola, A.M., Versiani, M.A., Biffi, J.C.G., Oliveira, R.P., and Pascon, E.A. (2004). A comparative histological evaluation of the biocompatibility of materials used in apical surgery. Int. Endod. J. $37,738-748$.

20. Swetha, B., Mathew, S., Murthy, B.S., Shruthi, N., and Bhandi, S.H. (2015). Determination of biocompatibility: A review. Int. Dent. Med. J. Adv. Res. 1, 1-6.

21. Torabinejad, M., and Chivian, N. (1999). Clinical applications of mineral trioxide aggregate. J. Endod. 25, 197205.

22. Tsesis, I., Rosen, E., Schwartz-Arad, D., and Fuss, Z. (2006). Retrospective evaluation of surgical endodontic treatment: traditional versus modern technique. J. Endod. 32, 412-416.

23. Wu, M.-K., and Wesselink, P.R. (1993). Endodontic leakage studies reconsidered. Part I. Methodology, application and relevance. Int. Endod. J. 26, 37-43. 